\title{
Auditory Alterations in Children Infected by Human Immunodeficiency Virus Verified Through Auditory Processing Test
}

\author{
Ana Claudia Figueiredo Frizzo ${ }^{4,5}$ Myriam de Lima Isaac 5,6 \\ ${ }^{1}$ Department of Phonoaudiology, Universidade de São Paulo, Ribeirão \\ Preto, São Paulo, Brazil \\ ${ }^{2}$ Department of Ophthalmology, Faculdade de Medicina de Ribeirão \\ Preto, Universidade de São Paulo, Ribeirão Preto, São Paulo, Brazil \\ ${ }^{3}$ Department of Otorhinolaryngology and Head and Neck Surgery, \\ Faculdade de Medicina de Ribeirão Preto, Universidade de São Paulo, \\ Ribeirão Preto, São Paulo, Brazil \\ ${ }^{4}$ Department of Phonoaudiology, Universidade Estadual Paulista, \\ Marília, São Paulo, Brazil \\ ${ }^{5}$ Department of Ophthalmology, Ribeirão Preto Medical School, \\ Universidade de São Paulo, Ribeirão Preto, São Paulo, Brazil \\ ${ }^{6}$ Department of Otorhinolaryngology and Head and Neck Surgery, \\ Ribeirão Preto Medical School, Universidade de São Paulo, Ribeirão \\ Preto, São Paulo, Brazil
}

Ana Carla Leite Romero ${ }^{1}$ Lívia Marangoni Alfaya ${ }^{1}$ Alina Sanches Gonçales ${ }^{2,3}$

Address for correspondence Ana Cláudia Figueiredo Frizzo, UNESP, Hygino Muzi Filho, 737, Mirante, Marília, SP, 17525-900, Brazil (e-mail: anacarla_Ir123@hotmail.com).

Int Arch Otorhinolaryngol 2017;21:86-91.

\begin{abstract}
Introduction The auditory system of HIV-positive children may have deficits at various levels, such as the high incidence of problems in the middle ear that can cause hearing loss. Objective The objective of this study is to characterize the development of children infected by the Human Immunodeficiency Virus (HIV) in the Simplified Auditory Processing Test (SAPT) and the Staggered Spondaic Word Test.

Methods We performed behavioral tests composed of the Simplified Auditory Processing Test and the Portuguese version of the Staggered Spondaic Word Test (SSW). The participants were 15 children infected by HIV, all using antiretroviral medication.

Results The children had abnormal auditory processing verified by Simplified Auditory Processing Test and the Portuguese version of SSW. In the Simplified Auditory Processing Test, $60 \%$ of the children presented hearing impairment. In the SAPT, the memory test for verbal sounds showed more errors (53.33\%); whereas in SSW, 86.67\% of the children showed deficiencies indicating deficit in figure-ground, attention, and memory auditory skills. Furthermore, there are more errors in conditions of background noise in both age groups, where most errors were in the left ear in the Group of 8-yearolds, with similar results for the group aged 9 years.

Conclusion The high incidence of hearing loss in children with HIV and comorbidity with

Keywords

- HIV

- child

- hearing several biological and environmental factors indicate the need for: 1) familiar and professional awareness of the impact on auditory alteration on the developing and learning of the children with HIV, and 2) access to educational plans and follow-up with multidisciplinary teams as early as possible to minimize the damage caused by auditory deficits.
\end{abstract}

received

November 4, 2015

accepted

January 24, 2016

published online

March 14, 2016
DOI http://dx.doi.org/

10.1055/s-0036-1580614. ISSN $1809-9777$.
Copyright $(2017$ by Thieme-Revinter

Publicações Ltda, Rio de Janeiro, Brazil
License terms

(1) () $९$ 


\section{Introduction}

The fact that children infected by the human immunodeficiency virus (HIV) have to cope with chronic problems that may lead to a developmental deficit due to biological alterations from the damages caused by the initial manifestation of the disease, opportunistic infections, congenital infections, ${ }^{1-5}$ or because of environmental factors. There is an important rate of orphanage and institutionalization, poverty, social stigmatization, susceptibility to frequent hospital admissions, which deprives the children from environmental stimulation. ${ }^{1,3,4,6-8}$

According to the literature, ${ }^{9-12}$ the Central Nervous System cells are clearly an important HIV secondary target and, even in the absence of viral load, detectable levels in the blood, the viral replication continues. ${ }^{9}$

Older children generally do not show rapidly progressive and catastrophic neurological manifestations as younger children do, but the exposition to antiretroviral therapy and the progression of the disease may leave neurological signs and symptoms such as irritability, lack of attention, deficit in several language levels, and damage in fine motor coordination. $^{13}$

These symptoms may aggravate in adolescence, mainly in the case of youngsters who were infected at birth and, therefore have a long history of antiretroviral treatments. In this case there is a predominance of cognitive problems in most patients, including attention and memory difficulties. ${ }^{11,13-15}$

The HIV-positive children's auditory system may present deficit in several levels, such as the high incidence of problems in the middle ear, ${ }^{2,3,16-18}$ the possible ototoxicity caused by some medications used for the opportunist infections' treatment, ${ }^{2,16}$ and the virus attack on the Central Nervous System. ${ }^{19}$

Studies reveal that children infected by HIV are susceptible to otolaryngology manifestations. Those that may cause hearing losses are frequent, such as an otitis media episode. 2,8,16-18,20-22 Moreover, many times the otolaryngology injury happens even before the HIV infection diagnosis. ${ }^{18}$

The sensory deprivation caused by hearing loss, even if a fluctuating hearing loss, may lead to a change in the perception of complex auditory stimuli, including speech. This auditory signal degradation may cause damage in sound representation and in auditory skills, which involve speech comprehension in noisy environments, auditory memory binaural integration, and temporal occurrences. ${ }^{23,24}$

This auditory signal degradation may cause damage in sound representation and in auditory skills, hindering language acquisition and development. ${ }^{3,25}$ In addition, fluid accumulation in the middle ear can produce noise, which distorts the sound perception by the cochlea. ${ }^{26}$

The same is reported by Matas et al, ${ }^{24}$ who emphasizes the inconsistency in childreńs sound detection caused by the fluctuating hearing loss due to recurring otitis episodes, damaging their central nervous system maturation and, consequently, the development of necessary auditory skills for auditory processing.

The American Speech-Language-Hearing Association (ASHA) defines Auditory Processing (AP) as the set of processes and mechanisms that occur inside the auditory system in response to an acoustic stimulus and are responsible for the following abilities or skills: sound localization and lateralization; auditory discrimination; auditory pattern recognition; temporal aspects of audition, including temporal integration, temporal discrimination, temporal ordering, and temporal masking; auditory performance in competing acoustic signals; and auditory performance with degraded acoustic signals. $^{27}$

Auditory Processing Disorder is characterized by a poor performance in one or more of the above skills, which often presents impact on reading, language comprehension, and learning.

Children with auditory processing disorder may have difficulty hearing in environments with background noise, following oral instructions, understanding rapid or degraded speech, and even respond inconsistently to auditory stimuli and present lack of attention, even if they have normal peripheral hearing. ${ }^{28}$ Moreover, they may have sound localization difficulty, poor music and singing skills, and problems with reading, writing, and learning. ${ }^{27}$

Since central auditory system-related problems may occur isolated or associated with other neurological and/or developmental factors, which may influence the cognitive development, a multidisciplinary team must be responsible for the disorder diagnosis, starting with a detailed anamnesis and including electrophysiological and behavioral tests, in addition to basic audiometric assessment, ${ }^{28}$ as well as to provide parameters on the maturation and development of the auditory pathway, assisting in the follow-up of the rehabilitation process evolution.

Considering the frequency of otologic, auditory, language, speech, and learning alterations observed in the population attended by the speech pathology service at the pediatrics unit of Special Unity of Infectious Disease Treatment (UETDI), the investigation of reception, analysis, and organization of acoustic information transmitted to the peripheral and central auditory system by the environment becomes essential. This study focuses on children infected by HIV who present high susceptibility to otologic and neurological alterations, in addition to environmental factors such as lack of stimulation due to maternal debility, frequent hospital admissions, among others. Therefore, our aim is to characterize the development of children infected by HIV in the Simplified Auditory Processing Test (SAPT) and Staggered Spondaic Word Test (SSW).

\section{Material and Methods}

The Project was submitted and approved by the Research Ethics Committee. We selected a group of subjects who met the research requirements, and formalized their participation with the signatures of the free informed consent by the responsible kin.

We excluded those who could compromise or had a medical report which could affect the comprehension and performance in the applied tests, including otoscopy changes, syndromes, clear neurological and psychological changes, neuropsychomotor development changes, language, and speech changes. 
The group consisted of 15 children infected by HIV, which were divided into two groups of eight and nine. All of them were using antiretroviral medication with multidisciplinary doctor supervision at the pediatrics unit of the university.

Initially, the subjects underwent otolaryngology assessment to verify the absence of clear signs of otologic impairment, identified through otoscopy.

We performed the procedures over two days, to prevent the children from getting tired and distracted during the assessment, thus, damaging their performance. When this procedure was impossible, breaks were taken and activities and/or snacks were offered, and we resumed the tests with the child's consent.

The subjects went through a basic audiometric assessment, which consisted of Pure-Tone Audiometry, percentage index of speech recognition, middle ear measures, and acoustic middle ear muscle reflex research, aiming to verify the functional integrity of peripheral auditory system. Next, we conducted the Simplified Auditory Processing Test (sound localization test in 5 directions, memory for verbal and nonverbal sounds test and cochlear-palpebral reflex research) and the Portuguese version of Staggered Spondaic Word Test.

The auditory processing test was composed of diotic tests (sound localization, and memory for verbal and nonverbal sound tests) and a dichotic test (SSW Test), as described below.

\section{Simplified Auditory Processing Test (SAPT)}

SAPT is presented in a diotic way, identical stimuli are presented to both ears simultaneously in a free area, which was composed by tests that assessed the sound localization, memory for verbal and nonverbal sounds, and cochlearpalpebral reflex research.

After instructing the child about the procedure of each test, we performed a previous presentation of the stimuli. Thus, it was possible to verify whether the test comprehension was suitable and, if necessary, we provided more instructions.

During the tests, the examiner paid attention to the child's behavior and necessity, reinforcing the instructions when necessary, making the assessment an interactive process.

All tests were performed in an environment with acoustic isolation and followed the principles proposed by literature. ${ }^{29,30}$

Sound Localization (SL): The examiner stood $20 \mathrm{~cm}$ away from the child, who had to find the percussion instrument (rattle) without visual support. We assessed five directions in relation to the child's head: the right side, the left side, above, behind, and in front.

We ensured the stimuli presented in front and behind did not assume the Zero Azimuth position, avoiding confusion in relation to the stimulus origin.

As for the response, the examiner asked the child to indicate the direction from where the sound was believed to come. A performance considered satisfactory was four or five correct responses, and mistakes were expected in the above, front, and behind directions.

Memory for Verbal Sounds (MVS): In this test, the children had to identify the sequence of verbal sounds formed through the combination of the syllables PA, TA, CA, and FA. ${ }^{31}$
Initially, we verified whether the child was able to properly produce the sounds used in the test. The subject had to repeat the sequence presented orally by the examiner. Four sequences were presented, and the first was experimental. In this case, a visual cue was allowed, although this did not happen in the other sequences.

The performance considered satisfactory was two or three correct answers.

Memory for Non-Verbal Sounds (MNVS): Non-verbal memory was assessed through the presentation of four sequences of musical instruments, in which sound frequency ranged from low to high.

First, the instruments were presented in a way that familiarized the child with the sounds; then, the experimental sequence was performed with a visual cue. Subsequently, the other sequences took place, without the help of visual cue. After the instruments' percussion, the children had to turn to the examiner indicating the sequence of instruments they believed they had listened to. Two or three correct answers were considered satisfactory.

Cochlear-Palpebral Reflexes (CPR): The examiner observed the presence or absence of cochlear-palpebral reflexes over the presentation of a brief stimulus of high intensity (90dB HL) next to the ear of the child.

Staggered Spondaic Word Test (SSW): The test Staggered Spondaic Word - SSW aims to measure the integrity of the central hearing. In the Portuguese version, called Recognition Test in Disyllabic Dichotic Task, stimuli are presented dichotic, in other words, different auditory stimuli are presented simultaneously in both ears assessing binaural integration and separation. ${ }^{31}$

The Portuguese test uses dissyllabic paroxytone compound words belonging to Brazilian Portuguese as sound stimuli, presented to the patient at $50 \mathrm{~dB} \mathrm{HL}$ above the arithmetic average of the tone thresholds in the frequencies $0.5,1$, and $2 \mathrm{KHz}$.

The test consists of forty items formed by four words each, with a total of 160 stimuli. Each ear is stimulated by two words. The stimulus starts at the right ear, alternating to the left ear, and so on.

The first and fourth words are presented isolated and separately to each of the person's ears, that is, without competition, referred to as right-ear non-competitive condition (RNC) and left-ear non-competitive condition (LNC). The second and third words are dichotically presented, that is, a word in each ear simultaneously, therefore there is competition (right-ear non-competitive condition - RNC; left-ear competitive condition - LNC). ${ }^{31}$

Initially, the child received instructions about the procedure of the test and had to repeat words heard at the headphone. In addition, the test itself presents a previous demonstration of some items so the patient is able to understand the task.

The examiner registered the types of mistakes made by the child in the registration sheet, aiming at obtaining the percentage of total mistakes made in the test, according to Borges proposal. ${ }^{32}$

A performance considered satisfactory for 8-year-old children was an index of correct answers equal to or above $84 \%$, 


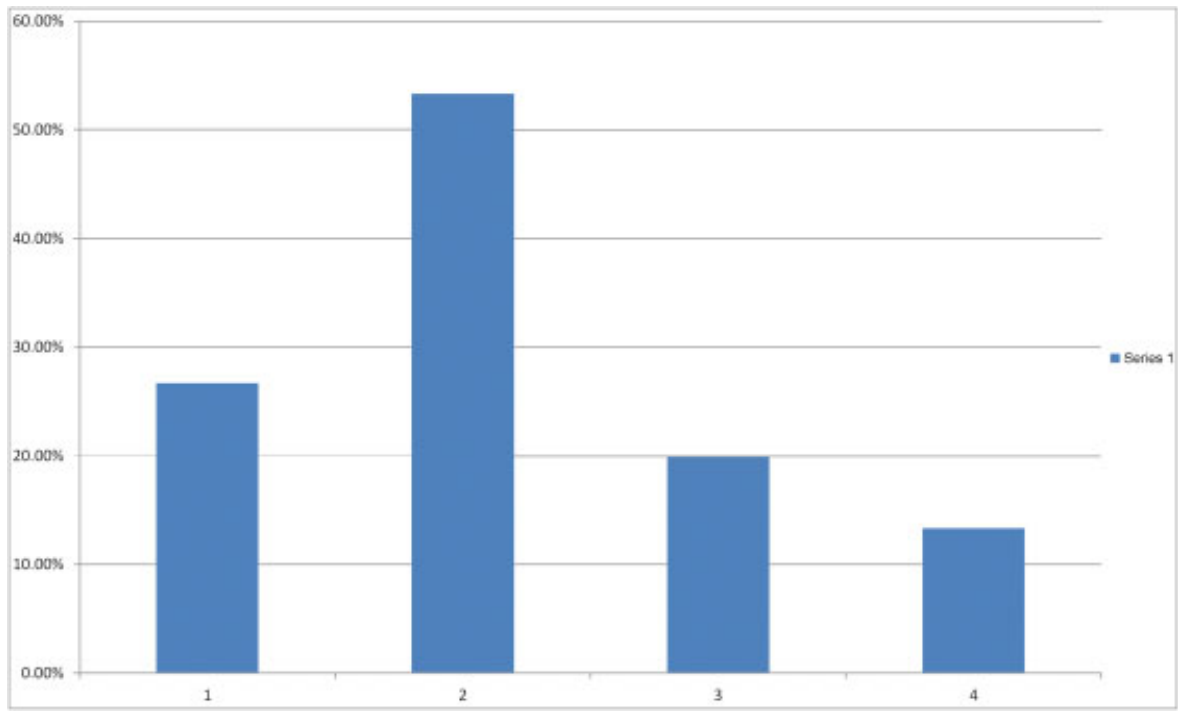

Fig. 1 Group performance in Simplified Auditory Processing Test.

and $90 \%$ for the 9-year-old children, according to the classification proposed by Borges. 32

We performed routine physical calibration of the equipment, as well as the tests biologic calibration according to that which is suggested by the literature. ${ }^{33}$

To analyze the data, we employed statistical procedures of the descriptive and analytical type, organizing results in tables presented in absolute numbers.

\section{Results}

The children infected by HIV presented auditory alterations related to the Auditory Processing verified through Simplified Auditory Processing Test and Portuguese version SSW Test.

In the SAPT, $60 \%$ of the children presented changes in at least one of the assessed auditory skills (-Fig. 1), and the highest index of errors was in the verbal sound memory test (-Fig. 2). Comparing the performance between the age groups, the 8-year-old group presented a higher index of errors $(66.70 \%)$ in relation to the 9-year-old group (33.30\%) (-Fig. 3).

In the SSW Test, $86.67 \%$ of the children showed impairments, indicating a greater deficit in attention, memory, and auditory figure-ground skills. Comparing the age groups in the SSW test, most errors were in the left ear of the 8-year-old group, which did not happen in the 9-yearold group, suggesting the proper maturation course (-Table 1).

The majority of changes in competitive conditions were observed in both age groups, as presented in -Table 2.

\section{Discussion}

Our findings are in accordance to those obtained in the literature. ${ }^{34}$ We performed the research on HIV-positive children and observed that they present high incidence of

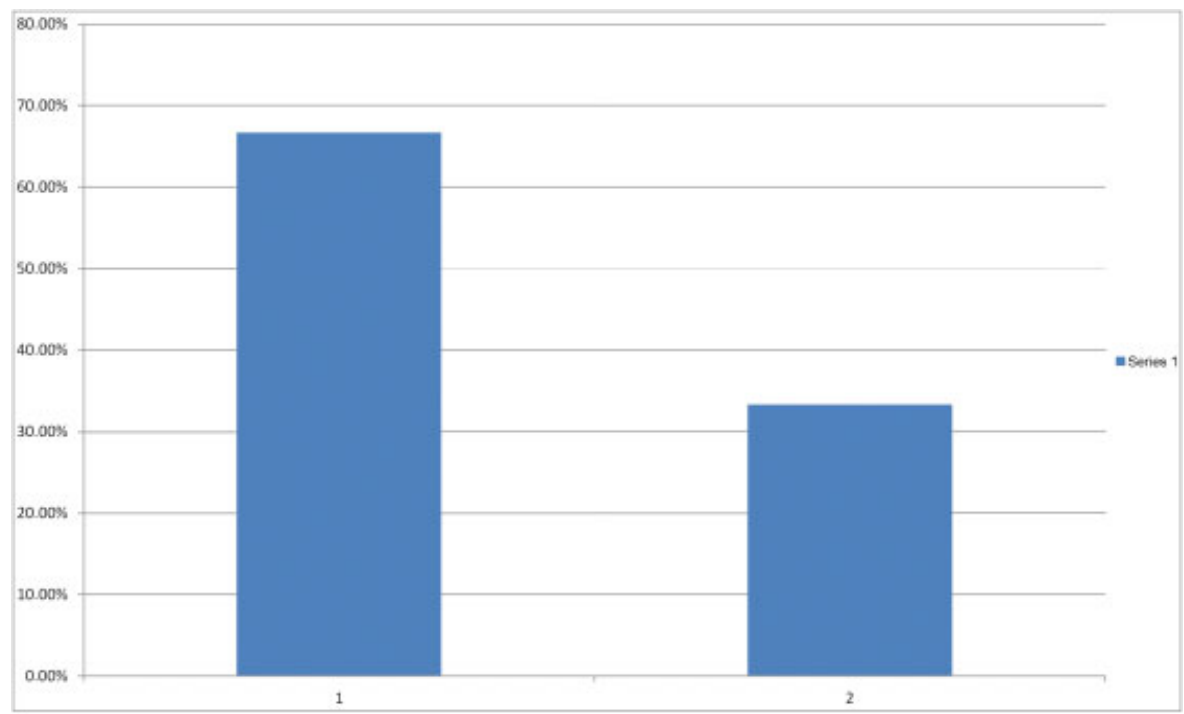

Fig. 2 Alterations sort observed in Simplified Auditory Processing Test. 


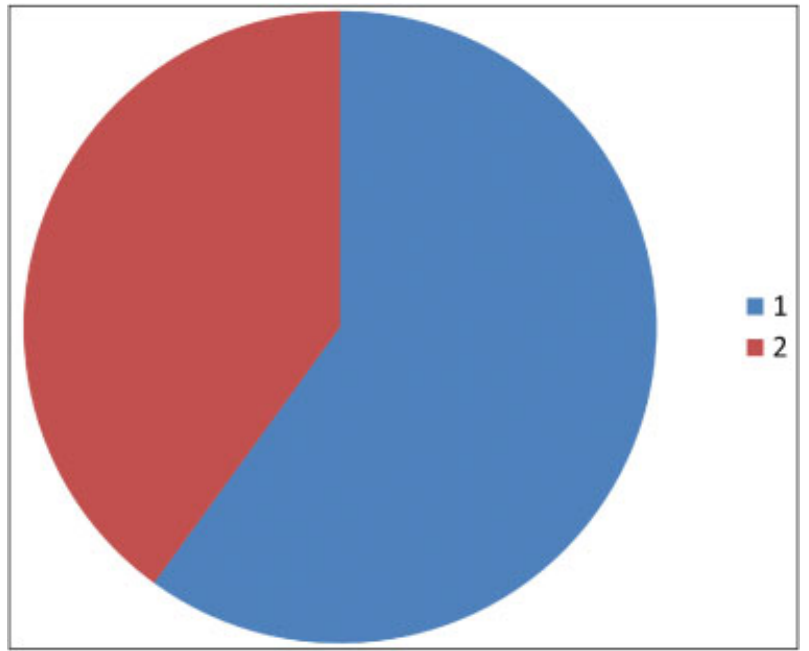

Fig. 3 Distribuition of alterations from Simplified Auditory Processing Test according with age.

auditory problems, both peripheral (mainly conductive resulting from the middle ear involvement in consequence of otitis media episodes) and central. The author suggests that the HIV presence should be considered a risk factor to peripheral and/or central auditory impairment.

The high incidence of changes in the SSW test suggests deficit in the skills involved in the test accomplishment: attention and auditory memory and auditory figure-ground, ability to focus attention to an auditory stimulus in the presence of background noise. This information is important in the learning process, given that the child must pay attention to an important sound stimulus among others occurring simultaneously. ${ }^{35}$

The prevalence of changes in the SSW test in relation to SAPT and the predominance of errors in the left ear in the group of 8 -year-olds and in the competitive condition are

Table 1 Mean number of errors in each ear in the SSW test according age group

\begin{tabular}{|l|l|l|}
\hline & Right Ear & Left Ear \\
\hline 8 years old & 17.00 & 25.17 \\
\hline 9 years old & 21.56 & 21.22 \\
\hline Total Average & 19.73 & 22.80 \\
\hline
\end{tabular}

Table 2 Mean number of errors in each condition in the SSW test according to age group

\begin{tabular}{|l|l|l|l|l|}
\hline & RENOC & REOC & LEOC & LENOC \\
\hline 8 years old & 5.17 & 11.83 & 14.50 & 6.00 \\
\hline 9 years old & 7.67 & 13.89 & 13.89 & 7.33 \\
\hline Total Average & 6.67 & 13.07 & 14.13 & 6.80 \\
\hline
\end{tabular}

Abbreviations: LENOC, left ear non-overlapping condition; LEOC, left ear overlapping condition; RENOC, right ear non-overlapping condition; REOC, right ear overlapping condition. probably justified by the differences in the way the test was presented (dichotic $x$ diotic) and by the fact that the maturation is not totally concluded in this age group.

The competitive stimuli cause more errors because the system needs to operate on its limits; the left ear makes more mistakes than the right ear due to the speech hemispheric dominance; and the younger the child, the more errors, which gradually decrease up to age 11 , when the auditory function maturation process ends and the results are similar to those in a normal adult. ${ }^{36}$

We must also consider the possibility of other interference factors, which may compromise the development of HIVpositive children. Authors ${ }^{37}$ investigated the role of the home environment, socioeconomic status, and cognitive functioning in children infected by HIV, and observed that the family environment may be an important mediator in the development process of HIV-positive children, especially for children in more advanced stages of the infection. The awareness of families and school regarding this possible risk must take place by means of individualized treatment.

We must emphasize that, with the improvement of antiretroviral treatment, there has been an increase in the life expectancy of children infected by HIV. ${ }^{24,38}$ Thus, it is essential to invest in the quality of life. In this aspect, early intervention with a multidisciplinary team focusing on the necessities is fundamental to the development of the necessary skills for the complex learning process. Smith et $\mathrm{al}^{1}$ point out on the plurality of factors that can cause cognitive deficits in children infected by HIV and suggest that some children may need educational support, psychosocial resources in the classroom, and regular reassessment of their progress and learning necessities. In this case, the speech therapist plays an important role in the prevention and rehabilitation of aspects related to HIV-positive children's audition, communication, and learning.

\section{Conclusion}

The children infected by HIV presented auditory alterations related to Auditory Processing. In the SAPT, $60 \%$ of the children presented alteration in at least one of the auditory skills assessed, and the highest index of errors observed was in the verbal sound memory test. Comparing the performance between the age groups, the 8-year-old group presented a higher index of errors in relation to the 9-year-old group.

In the SSW Test, $86.67 \%$ of the children showed impairments, indicating a greater deficit in the attention, memory, and auditory figure-ground skills. Comparing the age groups in the SSW test, most errors were in the left ear of the 8-yearold group, which did not happen in the 9-year-old group, suggesting the proper maturation course.

The high incidence of auditory alterations in children infected by HIV and the comorbidity with several factors, both biological and environmental, indicate the need to make professionals and family aware of the great impact the auditory alterations have in HIV-positive children's developing and learning process. Thus, it is recommended that such children have early access to individualized educational plans and treatment with a multidisciplinary team. 


\section{References}

1 Smith R, Malee K, Leighty R, et al; Women and Infants Transmission Study Group. Effects of perinatal HIV infection and associated risk factors on cognitive development among young children. Pediatrics 2006;117(3):851-862

2 Harris T, Bardien S, Schaaf HS, Petersen L, De Jong G, Fagan JJ. Uso de antibióticos aminoglicosídeos perda auditiva em HIV -positivos e HIV -negativos pacientes de tuberculose multirresistente. S Afr Med J 2012;102(6 Pt 2):363-366

3 Williams PL, Marino M, Malee K, Brogly S, Hughes MD, Mofenson LM; PACTG 219C Team. Neurodevelopment and in utero antiretroviral exposure of HIV-exposed uninfected infants. Pediatrics 2010;125(2):e250-e260

4 Joint United Nations Programme on HIV/AIDS - UNAIDS. Situação da epidemia de AIDS 2009 [Internet]. Accessed Nov 30, 2008. Available at: http://www.onu-brasil.org.br/agencias_unAIDS.php

5 Christo PP. Cognitive alterations associated with HIV-1 infection and AIDS. Rev Assoc Med Bras 2010;56(2):242-247

6 GUERRA CPP. SEIDL EMF. Crianças e adolescentes com HIV /AIDS: revisão de estudos sobre revelação do diagnóstico, adesão e estigma. Paidéia 2009;19:59-65

7 Lee GM, Gortmaker SL, McIntosh K, Hughes MD, Oleske JM; Pediatric AIDS Clinical Trials Group Protocol 219C Team. Quality of life for children and adolescents: impact of HIV infection and antiretroviral treatment. Pediatrics 2006;117(2):273-283

8 Brackis-Cott E, Kang E, Dolezal C, Abrams EJ, Mellins CA. Brief report: language ability and school functioning of youth perinatally infected with HIV. J Pediatr Health Care 2009;23(3):158-164

9 Chao LL, Lindgren JA, Flenniken DL, Weiner MW. ERP evidence of impaired central nervous system function in virally suppressed HIV patients on antiretroviral therapy. Clin Neurophysiol 2004; 115(7):1583-1591

10 Geffin R, McCarthy M. Innate immune responses to HIV infection in the central nervous system. Immunol Res 2013;57(1-3):292-302

11 Rice ML, Zeldow B, Siberry GK, et al; Pediatric HIVAIDS Cohort Study (PHACS). Evaluation of risk for late language emergence after in utero antiretroviral drug exposure in HIV-exposed uninfected infants. Pediatr Infect Dis J 2013;32(10):e406-e413

12 Dobrova-Krol NA, van IJzendoorn MH, Bakermans-Kranenburg MJ, Juffer F. Effects of perinatal HIV infection and early institutional rearing on physical and cognitive development of children in Ukraine. Child Dev 2010;81(1):237-251

13 Feitosa AC, Lima HJA, Caetano JAC, Andrade LM, Beserra EP. Terapia anti-retroviral: fatores que interferem na adesão de crianças com HIV/AIDS. Esc Anna Nery Rev Enferm 2008;12(3):515-521

14 Carey CL, Woods SP, Rippeth JD, Heaton RK, Grant I; HIV Neurobehavioral Research Center (HNRC) Group. Prospective memory in HIV-1 infection. J Clin Exp Neuropsychol 2006;28(4):536-548

15 Laughton B, Cornell M, Boivin M, Van Rie A. Neurodevelopment in perinatally HIV-infected children: a concern for adolescence. J Int AIDS Soc 2013;16:18603

16 Matas CG, Santos Filha VAV, Juan KR, Pinto FR, Gonçalves IC. Manifestações audiológicas em crianças e adultos com AIDS. Pró-Fono Rev At Ci 2010;22(2):269-274

17 Tshifularo M, Govender L, Monama G. Otolaryngological, head and neck manifestations in HIV-infected patients seen at Steve Biko Academic Hospital in Pretoria, South Africa. S Afr Med J 2013; 103(7):464-466

18 Vieira ABC, Greco DB, Teófilo MMM, Gonçalves DU. Otoneurological manifestations associated with antiretroviral therapy. Rev Soc Bras Med Trop 2008;41(1):65-69

19 Cruz HM, Combrinck MI, Joska JA. HIV transtornos neurocognitivos associados: esquema anti-retroviral, sistema nervoso central eficácia de penetração, e os resultados cognitivos. S Afr Med J 2013;103(10):758-762
20 Weber R, Neto CDP, Miziara ID, Filho BCA. Impacto da HAART na prevalência de otite média crônica em crianças brasileiras infectadas pelo HIV. Rev Bras Otorrinolaringol (Engl Ed) 2006; 2:509-514

21 Matas CG, Marcon BA, Silva SM, Gonçalves IC. Avaliação auditiva na Síndrome da Imunodeficiência Adquirida Hearing evaluation in Acquired Immunodeficiency Syndrome. Rev Soc Bras Fonoaudiol 2010;15:174-178

22 Torre P III, Zeldow B, Hoffman HJ, et al; Pediatric HIVAIDS Cohort Study. Hearing loss in perinatally HIV-infected and HIV-exposed but uninfected children and adolescents. Pediatr Infect Dis J 2012; 31(8):835-841

23 Goffi-Gomez MVS, Liberman PHP, Gonçalves IC, Schultz C. Audiologic Consequences of Ototoxicity: case Report with Deterioration of the Intelligibility of Speech. Applied Cancer Research 2009; 29(2):95-99

24 Matas CG, Iorio MC, Succi RC. Auditory disorders and acquisition of the ability to localize sound in children born to HIV-positive mothers. Braz J Infect Dis 2008;12(1):10-14

25 Pietrobon C. Aprendizado das habilidades auditivas. Fonoaudiologos.net [Internet] Guia de fonoaudiólogos no Brasil e artigos de fonoaudiologia, 2007. Accessed Septmeber 14, 2009. Available at: www.fonoaudiologos.net

26 Balbani APS, Montovani JC. [Impact of otitis media on language acquisition in children]. J Pediatr (Rio J) 2003;79(5):391-396

27 American Speech-Language-Hearing Association. (Central) Auditory Processing Disorders. ASHA, 2005. Available at: http://www. asha.org/members/deskref-journals/deskref/default. Accessed March 25, 2013

28 Jerger J, Musiek F. Report of the consensus conference on the diagnosis of auditory processing disorders in school-aged children. J Am Acad Audiol 2000;11(9):467-474

29 Pereira LD. Desordem do processamento auditivo central através de observação comportamental: organização de procedimentos padronizados. In: Pereira LD, Schochat E, Eds. Processamento Auditivo. São Paulo: Lovise; 1996:43-56

30 Pereira LD. Processamento Auditivo Central: Abordagem Passo a Passo. In: Pereira LD, Schochat E, eds. Processamento Auditivo Central: Manual de Avaliação. São Paulo: Lovise; 1997, 49-60

31 Corona AP, Pereira LD, Ferrite S, Rossi AG. Memória seqüencial verbal de três e quatro sílabas em escolares. Pró-Fono Rev At Ci 2005;17(1):27-36

32 Borges ACC. Dissílabos alternados SSW. In: Pereira LD, Schochat E, eds. Processamento auditivo central: Manual de avaliação.. São Paulo: Lovise; 1997:169-78

33 Kalil DM, Pereira LD, Schochat E. Informações técnicas a respeito da montagem, calibração e padronização dos testes especiais. In: Pereira LD, Schochat E, eds. Processamento Auditivo Central: Manual de Avaliação. São Paulo: Lovise; 1997:91-8

34 Christopher N, Edward T, Sabrina BK, Agnes N. The prevalence of hearing impairment in the 6 months- 5 years HIV/AIDS-positive patients attending paediatric infectious disease clinic at Mulago Hospital. Int J Pediatr Otorhinolaryngol 2013;77(2): 262-265

35 Neves IF, Schochat E. Maturação do processamento auditivo em crianças com e sem dificuldades escolares. Pró-Fono Rev At Ci 2005;17(3):311-320

36 Machado SF. Processamento auditivo: uma nova abordagem. São Paulo: Plexus Editora; 2003:140

37 Manfredi AKS, Zuanetti PA, Mishima F, Granzotti RBG. Triagem auditiva neonatal em recém-nascidos de mães soropositivas para o HIV. J Soc Bras Fonoaudiol 2011;23(4):376-380

38 Sharland M, Bryant PA. Paediatric HIV infection. Medicine 2009; $37: 371-373$ 